\title{
Financial inclusion and it's effect on poverty in Indonesia
}

\author{
Thomas Andrian*; Nurbetty Herlina Sitorus; Irma Febriana MK; \\ Stefanus Willy Chandra
}

Prodi Ekonomi Pembangunan, Fakultas Ekonomi dan Bisnis, Universitas Lampung

*E-mail korespodensi: Thomas.andrian@feb.unila.ac.id

\begin{abstract}
This study aims to analyze and determine the impact of Financial Inclusion in Indonesia and other macroeconomic variables on poverty rate in Indonesia. This study uses secondary data. Analysis method with the Random Effect Model (REM) approach. The results of this study indicate that the variable Bank Service Offices per 1,000 km ${ }^{2}$, Ratio of DPK, Ratio CRD have a negative and significant effect on poverty rate in 33 provinces in Indonesia in 2014-2018, and Unemployment Rate (UMP) has a positive and significant effect on poverty rate in 33 provinces in Indonesia in the 2014-2018 period. However, the variable Economic Growth and Inflation (INF) did not have a significant effect on poverty in 33 provinces in Indonesia in the 2014-2018 period. Measuring this dimension is still difficult to do and currently several international institutions were concerned about the development of financial inclusion.
\end{abstract}

Keywords: Financial inclusion, Poverty rate, Economic growth

\begin{abstract}
Abstrak
Penelitian ini bertujuan untuk menganalisis serta mengetahui dampak adanya Financial Inclusion di Indonesia serta variabel-variabel makro ekonomi lain terhadap tingkat kemiskinan di Indonesia. Penelitian ini menggunakan data sekunder. Metode analisis panel data regression analysis (metode regresi data panel) dengan pendekatan random effect model (REM). Hasil Penelitian ini menunjukkan bahwa variabel Rasio Kantor Layanan Bank per $1.000 \mathrm{~km}^{2}$, rasio DPK, Rasio CRD berpengaruh negatif dan signifikan terhadap tingkat kemiskinan di 33 Provinsi di Indonesia Periode 2014-2018, dan tingkat pengangguran berpengaruh positif dan signifikan terhadap tingkat kemiskinan di 33 Provinsi di Indonesia periode 2014-2018. Pengukuran terhadap dimensi ini masih sulit untuk dilakukan dan saat ini beberapa lembaga internasional yang peduli terhadap pengembangan inklusi keuangan.
\end{abstract}

Kata kunci: Financial Inclusion, Tingkat kemiskinan, Rasio kantor layanan bank

\section{PENDAHULUAN}

Pertumbuhan ekonomi Indonesia yang berkelanjutan ditunjukkan dengan adanya peningkatan pembangunan ekonomi yang lebih baik. Tetapi pada kenyataannya, meskipun pertumbuhan ekonomi Indonesia cenderung meningkat namun belum mencapai pertumbuhan yang berkualitas dimana pertumbuhan ekonomi Indonesia belum dapat dinikmati oleh semua lapisan masyarakat. Bagaimanapun, pembangunan harus menempatkan manusia sebagai pusat perhatian atau sebagai subjek yang berperan aktif, sedangkan proses pembangunannya harus menguntungkan semua pihak (Kadji, 2013).

Proses pertumbuhan ekonomi dan pembangunan yang berkualitas pada dasarnya harus menempatkan masalah kemiskinan, kelompok rentan, dan semakin meningkatnya pengangguran sebagai perhatian utama. Masalah-masalah tersebut sosial tersebut harus diwapadai karena dapat menjadi penyebab instabilitas yang sangat membahayakan pelaksanaan pembangunan. Permasalahan tersebut juga membawa pengaruh negatif, 
seperti semakin melonggarnya ikatan-ikatan sosial dan melemahnya nilai-nilai, serta hubungan antar manusia.

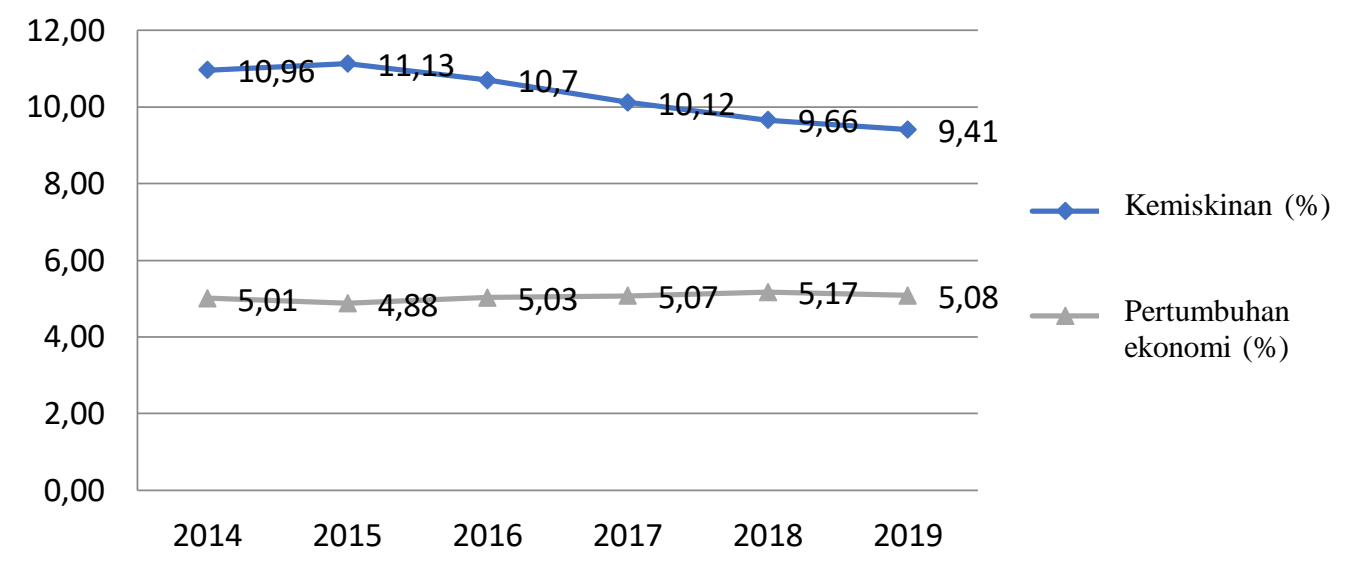

Gambar1. Perkembangan tingkat kemiskinan dan pertumbuhan ekonomi Indonesia Tahun 2014-2019

Sumber : Badan Pusat Statistik RI(diolah)

Gambar 1 menunjukkan perkembangan tingkat kemiskinan dan pertumbuhan ekonomi Indonesia periode 2014-2019 yang menampilkan gambaran rerata tingkat kemiskinan di 33 provinsi di Indonesia. Adapun provinsi yang tidak termasuk dalam penelitian ini yaitu Provinsi Kalimantan Utara karena provinsi ini relatif baru terbentuk sehingga dalam hal penghimpunan data menjadi pertimbangan dalam penelitian ini.

Melalui gambar ini dapat dilihat bahwa trend kemiskinan menurun seiring dengan pertumbuhan ekonomi yang stabil. Hal ini dapat menjadi pendorong untuk meningkatkan pentingnya upaya pemerintah untuk merancang dan menciptakan konsep yang lebih luas yang berkenaan dengan pertumbuhan ekonomi yang memungkinkan seluruh segmen masyarakat menikmati manfaat dari pertumbuhan ekonomi serta meningkatkan akses masyarakat terhadap jasa-jasa keuangan. Inklusifitas pertumbuhan ekonomi justru menjadi kebijakan yang sangat penting untuk mengurangi kemiskinan. Untuk mencapai tujuan ini, banyak negara berkembang termasuk Indonesia serius untuk mengembangkan sektor keuangan sebagai inti dari agenda pembangunan (Bank Indonesia, 2014). Tanpa menghilangkan financial barriers terhadap layanan jasa keuangan,masyarakat miskin akan tetap menjadi miskin secara terus menerus (Demirgüç-Kunt et al., 2008).

Aktivitas perekonomian suatu negara sangat bergantung pada sektor perbankan yang merupakan salah satu sektor yang menguasai industri keuangan, begitu juga dengan aktivitas perekonomian di Indonesia. Sektor perbankan memiliki aset terbesar dibandingkan dengan lembaga keuangan yang ada di industri keuangan Indonesia. Besarnya aset perbankan dibandingkan dengan lembaga keuangan lainnya yanga da di Indonesia menunjukkan bahwa perbankan merupakan lembaga keuangan yang mampu menarik konsumen lebih banyak dibandingkan dengan lembaga keuangan lainnya. Masyarakat Indonesia cenderung lebih memilih menyimpan asetnya di perbankan dalam bentuk dana pihak ketiga. Sektor perbankan juga menjadi salah satu sektor yang memberikan kontribusi terhadap pendapatan nasional dan dapat menciptakan pertumbuhan ekonomi. Bank merupakan lembaga perantara keuangan yang dapat menghubungkan pihak yang memiliki modal dengan pihak yang membutuhkan modal. Fungsi bank sebagai lembaga perantara keuangan dapat mengurangi biaya transaksi, pembagian risiko, dan informasi asimetris (Miskhin, 2008). Perantara keuangan memiliki peranan penting dalam meningkatkan efisiensi ekonomi karena membantu pasar 
keuangan menyalurkan dana kepada pihak yang mempunyai peluang investasi yang produktif. (Ummah, 2015).

Peningkatan sektor jasa keuangan dalam kurun waktu 5 tahun terakhir mengalami ekspansi yang semakin meluas, hal ini mengindikasikan bahwa layanan keuangan menjadi satu hal terpenting dalam upaya perbaikan kesejahteraan bagi masyarakatmenengah yang belum terbiasa dengan akses perbankan (unbanked). Pihak perbankan semakin kompetitif dalam melakukan inovasi terhadap produk yang mereka tawarkan kepada para nasabah. Hal ini juga membuat akses serta kondisi wilayah dan geografis menjadi satu target perbankan agar lebih dekat kepada masyarakat, juga agar tidak mengesankan bahwa jasa keuangan hanya milik sekelompok orang di daerah perkotaan saja. Masyarakat memiliki hambatan dalam mengakses lembaga keuangan. Tingginya unbankable people disebabkan karena garis kemiskinan antar provinsi, rendahnya pembiayaan UMKM, suku bunga kredit mikro tinggi, asymmetric information, kemampuan manajemen UMKM kurang memadai, monopoli bank pada sektor mikro, dan terbatasnya saluran distribusi jasa keuangan. Inilah yang menjadi alasan urgennya penerapan Financial Inclusion. Pada dasarnya, konsep sistem keuangan yang inklusif tidak hanya muncul sebagai program yang pro-growth, namun juga pro-jobs untuk masyarakat miskin (pro-poor).(Nasution, 2017).

\section{Tinjauan pustaka dan pengembangan hipotesis}

Inklusi keuangan (financial inclusion) adalah seluruh upaya yang bertujuan meniadakan segala bentuk hambatan yang bersifat harga maupun non harga, terhadap akses masyarakat dalam memanfaatkan layanan jasa keuangan. Inklusi keuangan juga merupakan strategi nasional untuk mendorong pertumbuhan ekonomi melalui pemerataan pendapatan, pengentasan kemiskinan serta stabilitas sistem keuangan.

Inklusi keuangan didefinisikan sebagai sebuah proses yangmenjamin kemudahan dalam akses, ketersediaan, dan manfaat dari sistem keuangan formal bagi seluruh pelaku ekonomi (Sarma, 2012). Tentunya dengan sistem keuangan yang inklusif dapat memberikan beberapa manfaat bagi masyarakat yang sebelumnya tidak tersentuh layanan keuangan untuk dapat menikmati akses terhadap layanan sistem keuangan.

Inklusi keuangan juga merupakan upaya untuk memasukkan masyarakat unbankable ke dalam sistem keuangan formal sehingga memiliki kesempatan untuk menikmati jasa-jasa keuangan seperti tabungan, pembayaran, serta transfer (Hannig and Jansen, 2010). Selain itu, inklusi keuangan merupakan sebuah proses yang menjamin kemudahan dalam akses, ketersediaan, dan manfaat dari sistem keuangan formal bagi seluruh pelaku ekonomi (Sarma, 2012). Sehingga dapat disimpulkan bahwa inklusi keuangan merupakan upaya meningkatkan akses masyarakat khususnya masyarakat unbankable ke dalam layanan jasa keuangan formal dengan mengurangi berbagai macam hambatan untuk mengaksesnya. Kegiatan keuangan inklusif menjadi salah satu agenda penting dalam dunia internasional. Forum internasional seperti G20, APEC, AFI, OECD dan ASEAN secara intensif melakukan pembahasan mengenai keuangan inklusif. Selain itu, keuangan inklusif juga telah masuk dalam 6 prioritas pemerintah Indonesia. Pada bulan Juni 2012, Bank Indonesia bekerjasama dengan Sekretariat Wakil Presiden - Tim Nasional Percepatan Penanggulangan Kemiskinan (TNP2K) dan Badan Kebijakan Fiskal - Kementerian Keuangan mengeluarkan Strategi Nasional Keuangan Inklusif. Strategi ini berisi kerangka kerja, implementasi dan langkah kedepan pelaksanaan keuangan inklusif.

Di India, inklusi keuangan menekankan pada proses untuk memastikan bahwa akses terhadap sistem jasa keuangan and kredit yang memadai bagi masyarakat miskin dengan biaya yang terjangkau (Rangrajan Committee, 2013). Hasil penelitian yang mengambil tempat penelitian di Peru mengungkapkan pentingnya perluasan akses bagi sebagai besar masyarakat terhadap portofolio produk dan jasa keuangan, seperti pinjaman, deposito, asuransi, pensiun, sistem pembayaran, serta mekanisme pendidikan 
keuangan dan perlindungan konsumen (Reyes, 2010). Di Indonesia, inklusi keuangan menjadi strategi nasional untuk mendorong pertumbuhan ekonomi melalui distribusi pendapatan yang merata, penurunan tingkat kemiskinan, danstabilittas sistem keuangan. Hak setiap individu dijamin untuk dapat mengakses seluruh cakupan kualitas jasa keuangan dengan biaya yang terjangkau. Target dari kebijakan ini sangat memperhatikan masyarakat miskin berpendapatan rendah, masyarakt miskin produktif, pekerja migran, dan masyarakat yang hidup di pelosok. (Bank Indonesia, 2014).

Pertumbuhan ekonomi regional di Indonesia memiliki hubungan negatif dengan tingkat kemiskinan dan hal ini sejalan dengan penelitian yang dilakukan oleh Retnowati (2017) yang menyatakan pertumbuhan ekonomi regional berpengaruh negatif terhadap tingkat kemiskinan, sehingga dengan meningkatnya pertumbuhan ekonomi regional dapat memacu kegiatan ekonomi masyarakat yang pada akhirnya mengurangi kemiskinan. Sementara itu, inflasi regional dan tingkat pengangguran regional diharapkan memiliki hubungan yang positif dengan tingkat kemiskinan dan juga hal ini diperkuat oleh hasil penelitian sebelumnya yang dilakukan oleh Ningsih (2018) yang menyatakan bahwa variabel inflasi berpengaruh positif terhadap tingkat kemiskinan dan juga lewat penelitian Siyan (2016) dan Hoover (2003) yang menyatakan bahwa variabel pengangguran berpengaruh positif terhadap tingkat kemiskinan, sehingga ketika inflasi meningkat akan memangkas pendapatan riil masyarakat sehingga semakin sulit memenuhi kebutuhannya yang pada akhirnya angka kemiskinan meningkat, begitu juga dengan tingkat pengganguran yang menandakan rendahnya produktivitas masyarakat dan pada akhirnya akan kesulitan dalam memenuhi kebutuhan pokok mereka sehingga kemiskinan akan meningkat.

\section{METODE}

Penelitian ini merupakan penelitian deskriptif kuantitatif dan data yang digunakan dalam penelitian ini merupakan data sekunder. Di dalam penelitian ini terdapat 6 variabel bebas(explanatory variables) yaitu indikator financial inclusion yang terdiri dari rasio kantor layanan bank per $1.000 \mathrm{~km}^{2}$ dari dimensi akses, rasio DPK/PDRB dan rasio kredit/PDRB dari dimensi penggunaan, inflasi regional, pertumbuhan ekonomi regional, dan pengangguran regional serta 1 variabel terikat(dependent variable) yaitu tingkat kemiskinan. Ruang lingkup penelitian ini mencakup 33 provinsi di Indonesia dengan menggunakan data 5 tahun terakhir yaitu 2014-2018.

Metode analisis yang digunakan dalam penelitian ini adalah metode Panel Data Regression Analysis (metode regresi data panel). Metode ini digunakan karena data panel merupakan gabungan dua jenis data, time series dan cross sectionyang mampu menyediakan data yang lebih banyak sehingga akan menghasilkan degree offreedomyang lebih besar dan dengan menggunakan data panel dapat mengatasi masalah penghilangan variabel (omitted-variable) (Widarjono, 2013).

\section{Regresi data panel}

Menurut Wibisono (2005) data panel adalah kombinasi dari data time series dan cross section. Data time series adalah merupakan data yang disusun berdasarkan urutan waktu, seperti data harian, bulanan, kuartal atau tahunan. Sedangkan data cross section merupakan data yang dikumpulkan pada waktu yang sama dari beberapa daerah, perusahaan atau perorangan. Penggabungan kedua jenis data dapat dilihat bahwa variabel terikat tingkat kemiskinan tediri dari beberapa unit provinsi (cross section), namun dalam berbagai periode waktu (time series). Data yang seperti inilah yang disebut dengan data panel. Dalam analisis model data panel dikenal tiga pendekatan yang terdiri dari Efek Sederhana/Umum (Common EffectModel), Efek Tetap (Fixed Effect Model), dan Efek Acak (Random Effect Model). 
Data panel memiliki beberapa kelebihan dibandingkan menggunakan data runtut waktu (time series) atau lintas individu (cross section) (Baltagi, 2005) antar lain: 1).Data panel mampu mengontrol heterogenitas individu. Data panel menganggap tiap-tiap individu, perusahaan, ataupun daerah bersifat heterogen. 2).Data panel memberikan informasi lebih lengkap, lebih variatif, dan lebih sedikit terjadi kolinieritas antar variabel dan derajat kebebasan (degree offreedom) yang lebih banyak. 3).Data panel lebih mampu untuk mengamati dinamika penyesuaian (dynamic of adjustment). 4).Data panel lebih mampu mengidentifikasi dan mengukur efek yang tidakterdeteksi pada data runtut waktu (time series) dan data lintas individu (cross section).5). Data panel memungkinkan untuk membangun dan menguji model perilaku yang lebih rumit daripada data runtut waktu (time series) dan data lintas individu (cross section). 6). Data panel diperoleh dari unit mikro sehingga bias-bias akibat agregasi individu atau perusahaan dapat direduksi dan dieliminasi. 7).Data panel dapat mengurangi bias dalam pengestimasian karena data cukup banyak.

Menurut Widarjono (2009), penggunaan data panel akan menghasilkan intersep dan koefisien kemiringan yang berbeda setiap individu dan periode waktu. Oleh karena itu berdasarkan asumsi yang dibuat tentang intersep, koefisien kemiringan, dan variabel gangguannya. Ada beberapa kemungkinan asumsi yang muncul, yaitu: 1).Intersep dan kemiringan (slope) adalah konstan menurut waktu dan individu. 2).Kemiringan (slope) tetap, namun intersep berbeda antar individu. 3).Kemiringan (slope) tetap, namun intersep berbeda antar individu dan antar waktu. 4).Semua koefisien (kemiringan dan intersep) berbeda antar individu. 5). Semua koefisien berbeda antar individu dan antar waktu.

\section{Model regresi}

Model regresi dalam penelitian ini sebagai berikut :

$$
\begin{aligned}
\mathrm{POV}_{i t}= & \beta_{0}+\beta_{1} \ln \_\mathrm{BANK} \\
& +\beta_{6} \mathrm{UMP}_{i t}+\mu_{i t} .(3.1)
\end{aligned}
$$

Keterangan :

$\mathrm{POV}=$ Tingkat kemiskinan

BANK = Rasio layanan bank per $1.000 \mathrm{~km}^{2}$

DPK $=$ Rasio DPK/PDRB

CRD $=$ Rasio Kredit/PDRB

$\mathrm{EG}=$ Pertumbuhan Ekonomi Regional

$\mathrm{INF}=$ Inflasi Regional

$\mathrm{UMP}=$ Pengangguran Regional

$\mathrm{i}=1,2, \ldots \mathrm{n}$, menunjukkan jumlah lintas individu (cross-section).

$\mathrm{t}=1,2, \ldots \mathrm{t}$, menunjukkan dimensi runtut waktu (time series).

$\beta_{0}=$ Konstanta (intercept).

$\beta_{1}, \beta_{2}, \beta_{3}, \beta_{4}$, dan $\beta_{5}=$ Koefisien regresi.

$\mu=$ Error term.

Dalam penelitian ini, peneliti menggunakan indikator-indikator inklusi keuangan yang telah dirumuskan dan disusun oleh Bank Indonesia yakni, dari dimensi penggunaan berupa total simpanan masyarakat yang terdiri dari tabungan, deposito, dan giro yang ada di bank komersial terhadap PDRB dan total kredit yang diberikan oleh bank komersial terhadap PDRB yang pengaruhnya diharapkan negatif dan juga hal ini bersesuaian dengan hasil penelitian sebelumnya yang telah dilakukan oleh Abimbola dkk (2018) dan Bakari (2019) yang menyebutkan lewat hasil penelitiannya bahwa variabel savings dan credit memiliki pengaruh yang negatif terhadap kemiskinan. Pemilihan 2 rasio dari sisi penggunaan (usage) dalam inklusi keuangan dalam penelitian ini didasarkan pada kemudahan mengakses data dalam rasio tersebut dan juga 2 rasio cukup mewakili dimensi 
penggunaan dari inklusi keuangan dalam penelitian ini. Berikutnya dari dimensi akses, peneliti menggunakan indikator rasio jumlah kantor layanan bank per $1.000 \mathrm{~km}^{2}$ yang diharapkan memiliki pengaruh yang negatif terhadap kemiskinan dan hal ini juga sejalan dengan hasil penelitian sebelumnya yang telah dilakukan oleh Harley Tega Williams (2017) yang menyatakan bahwa variabel kantor cabang bank umum memiliki kaitan erat dengan GDP sehingga diharapkan dengan hasil ini dapat mengurangi tingkat kemiskinan.Pemilihan rasio jumlah kantor layanan bank per $1.000 \mathrm{~km}^{2}$ dalam dimensi akses (access) juga didasarkan pada kemudahan dalam penghimpunan data dan juga rasio ini sudah cukup mewakili dimensi akses dalam inklusi keuangan yang keberadaannya cukup dekat dengan masyarakat umum.Ketiga variabel indikator Financial Inclusion tersebut tentunya diharapkan memiliki pengaruh yang negatif terhadap angka kemiskinan di provinsi-provinsi di Indonesia karena dengan meningkatnya akses dan layanan perbankan dapat membantu masyarakat dalam memenuhi kebutuhannya dan serta meningkatkan efisiensi ekonomi sehingga pada gilirannya akan mengurangi kesenjangan dan meningkatkan kesejahteraan masyarakat yang berujung pada penurunan angka kemiskinan.

Selain dari sisi inklusi keuangan, peneliti juga menggunakan variabel yang dapat mempengaruhi kemiskinan, diantaranya, pertumbuhan ekonomi regional, inflasi regional, dan tingkat pengangguran regional. Pertumbuhan ekonomi regional memiliki hubungan negatif dengan tingkat kemiskinan dan hal ini sejalan dengan penelitian yang dilakukan oleh Retnowati (2017) yang menyatakan pertumbuhan ekonomi regional berpengaruh negatif terhadap tingkat kemiskinan, sehingga dengan meningkatnya pertumbuhan ekonomi regional dapat memacu kegiatan ekonomi masyarakat yang pada akhirnya mengurangi kemiskinan. Sementara itu, inflasi regional dan tingkat pengangguran regional diharapkan memiliki hubungan yang positif dengan tingkat kemiskinan dan juga hal ini diperkuat oleh hasil penelitian sebelumnya yang dilakukan oleh Ningsih (2018) yang menyatakan bahwa variabel inflasi berpengaruh positif terhadap tingkat kemiskinan dan juga lewat penelitian Siyan (2016) dan Hoover (2003) yang menyatakan bahwa variabel pengangguran berpengaruh positif terhadap tingkat kemiskinan, sehingga ketika inflasi meningkat akan memangkas pendapatan riil masyarakat sehingga semakin sulit memenuhi kebutuhannya yang pada akhirnya angka kemiskinan meningkat, begitu juga dengan tingkat pengganguran yang menandakan rendahnya produktivitas masyarakat dan pada akhirnya akan kesulitan dalam memenuhi kebutuhan pokok mereka sehingga kemiskinan akan meningkat.

\section{HASIL DAN PEMBAHASAN}

Berdasarkan Gujarati (2012), apabila $i$ (jumlah unit cross section) lebih besar dibandingkan $t$ (jumlah rentang waktu) maka model efisien dan tepat untuk menguji dan menganalisis data dalam penelitian ini adalah menggunakan metode Random Effect Model (REM) Metode Randon Effect Model (REM) juga dapat mengatasi inefisiensi parameter dalam metode Fixed Effect Model (FEM) karena penggunaan variabel dummyyang berimbas pada berkurangnya derajat kebebasan (degree of freedom) sehingga menghasilkan parameter yang tidak lagi efisien.

Berdasarkan Tabel 7, variabel ln_BANK memiliki nilai t-statistik sebesar 1,876 lebih tinggi nilainya dari t-tabel yang sebesar 1,654 sehingga dapat disimpulkan variabel ln_BANK menolak $\mathrm{H}_{0}$ yang berarti variabel $\mathrm{ln} \_$BANK memiliki pengaruh signifikan terhadap tingkat kemiskinan 33 provinsi di Indonesia tahun 2014-2018 pada tingkat kepercayaan 95\%. Variabel ln_DPK memiliki nilai t-statistik sebesar 2,155 lebih tinggi nilainya dari t-tabel yang sebesar 1,654 sehingga dapat disimpulkan variabel ln_DPK menolak $\mathrm{H}_{0}$ yang berarti variabel ln_DPK memiliki pengaruhsignifikan terhadap tingkat kemiskinan 33 provinsi di Indonesia tahun 2014-2018 pada tingkat kepercayaan $95 \%$. 
Tabel 4. Estimasi data panel dengan metode Random Effect Model (REM).

\begin{tabular}{|c|c|c|}
\hline \multicolumn{3}{|c|}{ Variabel Terikat $(Y)=$ Tingkat Kemiskinan } \\
\hline \multirow{2}{*}{ Variabel Bebas } & \multicolumn{2}{|c|}{ Metode Regresi } \\
\hline & REM & Prob. \\
\hline $\mathrm{C}$ & 6,947 & 0,000 \\
\hline ln_BANK & $-1,043$ & 0,062 \\
\hline ln_DPK & $-1,871$ & 0,032 \\
\hline $\ln \_\mathrm{CRD}$ & $-2,453$ & 0,000 \\
\hline EG & $-0,002$ & 0,927 \\
\hline INF & $-0,017$ & 0,439 \\
\hline UMP & 0,124 & 0,051 \\
\hline R-squared & & \\
\hline Adj R-squared & & \\
\hline F-statistic & & \\
\hline
\end{tabular}

Sumber: Data diolah, 2020

Variabel ln_CRD memiliki nilai t-statistik sebesar 4,307 lebih tinggi nilainya dari t-tabel yang sebesar 1,654 sehingga dapat disimpulkan variabel ln_CRD menolak $\mathrm{H}_{0}$ yang berarti variabel ln_CRD memiliki pengaruh signifikan terhadap tingkat kemiskinan 33 provinsi di Indonesia tahun 2014-2018 pada tingkat kepercayaan 95\%. Variabel EG memiliki nilai t-statistik sebesar 0,091 lebih rendah nilainya dari t-tabel yang sebesar 1,654 sehingga dapat disimpulkan variabel $\mathrm{EG}$ menerima $\mathrm{H}_{0}$ yang berarti variabel $\mathrm{EG}$ memiliki pengaruh yang tidak signifikan terhadap tingkat kemiskinan 33 provinsi di Indonesia tahun 2014-2018 pada tingkat kepercayaan 95\%.

Variabel INF memiliki nilai t-statistik sebesar 0,775 lebih rendah nilainya dari ttabel yang sebesar 1,654 sehingga dapat disimpulkan variabel INF menerima $\mathrm{H}_{0 y a n g}$ berarti variabel INF memiliki pengaruh yang tidak signifikan terhadap tingkat kemiskinan 33 provinsi di Indonesia tahun 2014-2018 pada tingkat kepercayaan 95\%. Variabel UMP memiliki nilai t-statistik sebesar 1,959 lebih tinggi nilainya dari t-tabel yang sebesar 1,654 sehingga dapat disimpulkan variabel UMP menolak $\mathrm{H}_{0}$ yang berarti variabel UMP memiliki pengaruh signifikan terhadap tingkat kemiskinan 33 provinsi di Indonesia tahun 2014-2018 pada tingkat kepercayaan 95\%. Dapat disimpulkan melalui hasi uji t-statistik dalam Tabel 7, diperoleh hasil bahwa terdapat 4 variabel bebas yang berpengaruh signifkan terhadap tingkat kemiskinan 33 provinsi di Indonesia tahun 2014-2018 yakni, variabel ln_BANK (Rasio Kantor Layanan Bank per $1.000 \mathrm{~km}^{2}$ ), variabel ln_DPK (DPK/PDRB), variabel ln_CRD (Kredit/PDRB) dan variabel UMP (Tingkat Pengangguran), sedangkan variabel EG (Pertumbuhan Ekonomi), dan INF (Inflasi) memiliki pengaruh yang tidak signifikan terhadap tingkat kemiskinan 33 provinsi di Indonesia tahun 2014-2018.

\section{Rasio kantor layanan bank per $1.000 \mathrm{~km}^{2}$ (Bank) dan hubungannya dengan tingkat kemiskinan}

Berdasarkan hasil estimasi yang dilakukan sebelumnya dengan metode Random Effect Model (REM), variabel ln_BANK (rasio kantor layanan bank per $1.000 \mathrm{~km}^{2}$ ) memiliki pengaruh negatif dan signifikan terhadap tingkat kemiskinan di 33 provinsi di Indonesia tahun 2014-2018 dengan koefisien regresi sebesar -1,043 dengan tingkat kepercayaan 95\% yang dapat diartikan apabila variabel ln_BANK (rasio kantor layanan bank per $1.000 \mathrm{~km}^{2}$ ) mengalami kenaikan 1 persen, maka akan menurunkan tingkat kemiskinan di 33 provinsi di Indonesia sebesar 1,043 persen, ceteris paribus. Hal ini tentu sejalan dengan konsep Financial Inclusion yang menjamin kemudahan dalam akses, ketersediaan, dan juga manfaat dari sistem keuangan formal yang sesuai dan terjangkau bagi seluruh pelaku ekonomi. Hasil estimasi ini pula bersesuaian dengan hasil penelitian 
yang dilakukan oleh Abimbola dkk. (2018) yang menyebutkan bahwa variabel kantor layanan bank memiliki pengaruh negatif terhadap angka kemiskinan di wilayah penelitiannya. Hasil estimasi ini tentu memenuhi hipotesis dalam penelitian ini yang menyebutkan bahwa variabel rasio kantor layanan bank per $1.000 \mathrm{~km}^{2}$ (BANK) memiliki pengaruh negatif terhadap tingkat kemiskinan di 33 provinsi di Indonesia tahun 20142018.

Hasil penelitian ini dapat dimaknai bahwa sistem keuangan inklusif dapat menjadi strategi besar pembangunan ekonomi, penanggulangan kemiskinan, pemerataan pendapatan serta stabilitas sistem keuangan yang dapat memberikan akses terhadap jasa keuangan yang lebih luas bagi setiap penduduk khususnya kelompok miskin dan marjinal yang memiliki keterbatasan akses terhadap layanan keuangan. Dengan adanya kesempatan akses yang lebih luas lagi terhadap layanan jasa keuangan diharapkan dapat membuat masyarakat menjadi lebih sejahtera dan mendorong pendapatan masyarakat miskin semakin meningkat sehingga kesenjangan pendapatan dan kemiskinan itu sendiri dapat berkurang.

\section{Rasio DPK/PDRB (DPK) dan hubungannya dengan tingkat kemiskinan}

Berdasarkan hasil estimasi yang dilakukan sebelumnya, variabel ln_DPK (rasio DPK/PDRB) memiliki pengaruh negatif dan signifikan terhadap tingkat kemiskinan di 33 provinsi di Indonesia tahun 2014-2018 dengan koefisien regresi sebesar -1,871 dengan tingkat kepercayaan 95\% yang dapat diartikan apabila variabel ln_DPK (rasio DPK/PDRB) mengalami kenaikan 1 persen, maka akan menurunkan tingkat kemiskinan di 33 provinsi di Indonesia sebesar 1,871 persen, ceteris paribus. Hal ini sejalan dengan penelitian yang dilakukan oleh Bakari dkk. (2019) yang menyebutkan lewat hasil penelitiannya bahwa savings yang dalam hal ini rasio DPK/PDRB memiliki pengaruh negatif terhadap tingkat kemiskinan.

Hasil penelitian ini juga sesuai dengan penelitian yang dilakukan oleh Abimbola dkk. (2018) yang menyatakan lewat hasil penelitiannya bahwa tabungan yang dihimpun oleh perbankan memiliki pengaruh negatif terhadap tingkat kemiskinan. Dengan adanya hubungan negatif dan signifikan antara rasio DPK/PDRB dengan tingkat kemiskinan mengindikasikan perlu adanya sistem keuangan yang lebih bersifat inklusif sebagai upaya untuk mengurangi Financial Exclusion dan juga turut meningkatkan akses orang-orang yang unbanked ke dalam sistem perbankan untuk menikmati layanan sistem keuangan. Hasil penelitian ini juga dapat diartikan bahwa dengan semakin meningkatkan rasio DPK/PDRB ini menandakan bahwa semakin banyaknya masyarakat yang masuk dalam sistem keuangan itu sendiri yang membuat sistem keuangan semakin bersifat inklusif. Secara empiris, dapat dikatakan bahwa dalam penelitian ini variabel DPK (rasio DPK/PDRB) memiliki pengaruh negatif terhadap tingkat kemiskinan di 33 provinsi di Indonesia tahun 2014-2018.

\section{Rasio kredit/PDRB (CRD) dan hubungannya dengan tingkat kemiskinan}

Hasil estimasi yang telah dilakukan sebelumnya, diperoleh hasil bahwa variabel ln_CRD (kredit/PDRB) memiliki pengaruh negatif dan signifikan terhadap tingkat kemiskinan di 33 provinsi di Indonesia tahun 2014-2018. Variabel CRD (kredit/PDRB) memiliki koefisien regresi sebesar 2,453 dengan tingkat kepercayaan 95\%. Ini dapat diartikan bahwa apabila variabel ln_CRD (kredit/PDRB) mengalami peningkatan sebesar 1 persen, maka akan menurunkan tingkat kemiskinan sebesar 2,453 persen di 33 provinsi di Indonesia, ceteris paribus. Hal ini sejalan dengan penelitian yang dilakukan oleh Bakari dkk. (2019) yang menunjukkan bahwa kredit memiliki pengaruh negatif dengan tingkat kemiskinan.

Selain itu, hipotesis dalam penelitian ini yang menyebutkan bahwa variabel ln_CRD (kredit/PDRB) berpengaruh negatif terhadap tingkat kemiskinan didukung oleh 
hasil penelitian oleh Coulibali (2016) dan Abimbola dkk. (2018) yang menyebutkan bahwa pinjaman kepada masyarakat yang dalam hal ini kredit memiliki pengaruh negatif terhadap tingkat kemiskinan. Hal ini semakin membuktikan dan menguatkan bahwa variabel ln_CRD (kredit/PDRB) memegang peranan yang cukup penting dalam upaya pengentasan kemiskinan di Indonesia karena dengan adanya kredit, masyarakat dapat memenuhi kebutuhan hidupnya untuk meningkatkan taraf hidup masyarakat, memperluas kesempatan kerja serta dapat mengalokasikan sumber daya yang produktif semakin efisien sehingga aktivitas ekonomi akan meningkat yang pada gilirannya akan memicu pertumbuhan ekonomi dan juga menurunkan angka kemiskinan di wilayah tersebut.

\section{Pertumbuhan ekonomi dan hubungannya dengan tingkat kemiskinan}

Berdasarkan hasil estimasi yang telah dilakukan dengan metode Random Effect Model (REM), variabel EG (pertumbuhan ekonomi) memiliki pengaruh negatif dan tidak signifikan terhadap tingkat kemiskinan di 33 provinsi di Indonesia tahun 2014-2018. Variabel EG (pertumbuhan ekonomi) memiliki koefisien regresi sebesar 0,002 dengan tingkat kepercayaan 95\% dan dapat diartikan bahwa apabila variabel EG (pertumbuhan ekonomi) mengalami peningkatan sebesar 1 satuan maka akan menurunkan angka kemiskinan sebesar 0,002 persen, ceteris paribus. Hasil penelitian ini sejalan dengan penelitian yang dilakukan oleh Harnoto (2008), Retnowati (2017), serta Abimbola dkk. (2018) yang menyatakan bahwa pertumbuhan ekonomi berpengaruh negatif terhadap tingkat kemiskinan.

Sementara itu, dengan tidak ditemukannya pengaruh signifikan antara pertumbuhan ekonomi dengan tingkat kemiskinan sejalan dengan penelitian yang dilakukan oleh Barika (2013) dan Zuhdiyati (2017) yang turut mengindikasikan bahwa pertumbuhan ekonomi yang ada lebih banyak ditopang oleh sektor konsumsi daripada sektor investasi ataupun pembentukan modal, sehingga kualitas pertumbuhan ekonomi tidak begitu baik dan besar perannya dalam hal mengurangi angka kemiskinan. Hal lainnya adalah pertumbuhan ekonomi yang terjadi tidak diikuti dengan perbaikan dalam pemerataan pendapatan, sehingga kenaikan perekonomian hanya dinikmati oleh sebagian kelompok tertentu, sementara golongan masyarakat miskin belum terlalu mendapat dampak dari pertumbuhan ekonomi yang ada. Hasil penelitian ini memberikan implikasi bahwa pertumbuhan ekonomi di Indonesia dari periode 2014-2018 belum cukup mampu dan signifikan untuk mengurangi angka kemiskinan di 33 provinsi di Indonesia periode 20142018. Hal ini dibuktikan dengan adanya kualitas pertumbuhan ekonomi yang kurang baik ditandai dengan kecilnya penurunan angka ketimpangan Indonesia tercermin dari Gini Ratio yang hanya bergerak sebesar 2,8\% dalam 5 tahun terakhir sedangkan pergerakan pertumbuhan Indonesia dalam 5 tahun terakhir tumbuh sebesar 7\%. Belum signifikannya pertumbuhan ekonomi terhadap angka kemiskinan dipengaruhi pula oleh pertumbuhan penduduk di Indonesia yang terus meningkat setiap tahunnya yang akan mengurangi angka pendapatan per kapita Indonesia sehingga pertumbuhan ekonomi Indonesia, dampaknya belum dapat dirasakan oleh masyarakat miskin, oleh karenanya pertumbuhan ekonomi hendaknya menyebar di setiap golongan pendapatan, termasuk di golongan penduduk miskin seperti di sektor pertanian ataupun sektor padat karya, sehingga pertumbuhan ekonomi yang ada dapat terdistribusi secara lebih merata yang harapannya dapat mengurangi angka kemiskinan di Indonesia.

\section{Inflasi dan hubungannya dengan tingkat kemiskinan}

Hasil estimasi yang telah dilakukan menunjukkan bahwa variabel INF (inflasi) memiliki pengaruh negatif dan tidak signifikan terhadap tingkat kemiskinan di 33 provinsi di Indonesia tahun 2014-2018. Variabel INF (inflasi) memiliki koefisien regresi sebesar 0,017 dengan tingkat kepercayaan sebesar 95\%. Angka koefisien regresi ini dapat diartikan bahwa apabila variabel INF (inflasi) mengalami kenaikan sebesar 1 satuan, 
maka akan menurunkan angka kemiskinan sebesar 0,017 persen, ceteris paribus. Hal ini tentu berlawanan dengan teori dan paradigma ekonomi yang menyatakan bahwa dengan naiknya harga barang dan jasa yang kita konsumsi setiap harinya maka dengan jelas akan menurunkan daya beli masyarakat terutama masyarakat yang berpendapatan menengah ke bawah yang turut berkontribusi pada peningkatan angka kemiskinan yang terjadi di wilayah tersebut dimana peningkatan harga pada komoditi makanan memiliki dampak yang relatif jauh lebih besar terhadap kemiskinan dibandingkan dengan inflasi yang terjadi pada komoditi non pangan. Inflasi memberikan beban yang relatif jauh lebih besar bagi penduduk miskin di Indonesia baik di perkotaan maupun pedesaan dibandingkan dengan yang dirasakan oleh penduduk non-miskin.

Hasil estimasi ini sejalan dengan hasil penelitian yang dilakukan oleh Meinny Kolibu, dkk, yang menyebutkan bahwa inflasi memiliki pengaruh negatif dan tidak signifikan terhadap angka kemiskinan. Hasil ini memberikan implikasi bahwa pengaruh inflasi terhadap kemiskinan di Indonesia pengaruhnya tidak siginifkan ataupun berarti, hal ini dikarenakan keberhasilan pemerintah dalam upaya untuk menjaga stabilitas inflasi periode 2014-2018 terutama inflasi pada sub-sektor makanan atau bahan pangan. Bahan makanan memberikan kontribusi besar terhadap pengeluaran rumah tangga secara umum.Berdasarkan data Badan Pusat Statistik (BPS) per Maret 2018, menyebutkan, bahan makanan berkontribusi 71,04 persen terhadap garis kemiskinan yang mana artinya, ada hubungan yang kuat antara penurunan kemiskinan dengan stabilnya inflasi. Capaian pengendalian harga ini sangat penting, karena harga pangan memberikan kontribusi yang sangat besar terhadap kemiskinan. Merujuk data dari Badan Pusat Statistik (BPS), ratarata inflasi bahan makanan dari 2009 hingga 2013 yakni mencapai 8,04 persen, sementara pada periode 2014-2018, rata-rata inflasi bahan makanan sebesar 5,17 persen. Dengan demikian, pengaruhnya inflasi yang meningkatkan angka kemiskinan dalam penelitian tidak terdukung dalam hipotesis penelitian.

\section{Tingkat pengangguran dan hubungannya dengan tingkat kemiskinan}

Berdasarkan hasil estimasi yang telah dilakukan sebelumnya menunjukkan bahwa variabel UMP (tingkat pengangguran) memiliki pengaruh positif dan signifikan terhadap tingkat kemiskinan di 33 provinsi di Indonesia tahun 2014-2018. Variabel UMP (tingkat pengangguran) memiliki koefisien regresi sebesar 0,124 dengan tingkat kepercayaan sebesar 95\%. Angka koefisien regresi ini dapat diartikan bahwa apabila variabel UMP (tingkat pengangguran) mengalami kenaikan sebesar 1 satuan, maka akan meningkatkan pula angka kemiskinan sebesar 0,124 persen, ceteris paribus. Hasil penelitian ini memenuhi hipotesis dalam penelitian ini yang menyebutkan bahwa tingkat pengangguran berpengaruh positif terhadap tingkat kemiskinan dan juga bersesuaian dengan hasil penelitian yang dilakukan oleh Hoover (2003), Retnowati (2017), Siyan dkk (2016) menyatakan bahwa terdapat hubungan yang kuat dan searah antara tingkat pengangguran dan tingkat kemiskinan yang terjadi di masing-masing wilayah penelitian.

Dengan hasil ini, semakin menguatkan bahwa masalah ketenagakerjaan sangat dekat dan dapat menimbulkan masalah dalam perekonomian dimana saat tingkat pengangguran yang tinggi mengindikasikan rendahnya produktivitas dan pendapatan yang dapat dihasilkan, yang akan meningkatkan peluang masyarakat yang menganggur masuk ke dalam kemiskinan sehingga dengan demikian, pertumbuhan ekonomi dan peningkatan kemakmuran bagi masyarakat sulit dicapai yang pada gilirannya akan memicu naiknya angka kemiskinan di wilayah tersebut. Hasil ini juga sekaligus menegaskan bahwa salah satu strategi paling efektif untuk mengurangi kemiskinan adalah dengan memperluas dan menciptakan berbagai lapangan pekerjaan.

\section{KESIMPULAN DAN SARAN}




\section{Kesimpulan}

Variabel bank yang mewakili dimensi akses (rasio kantor layanan bank umum per $1.000 \mathrm{~km}^{2}$ ) berpengaruh negatif dan signifikan terhadap tingkat kemiskinan di 33 provinsi di Indonesia periode 2014-2018. Variabel rasio DPK/PDRB yang mewakili dimensi penggunaan berpengaruh negatif dan signifikan terhadap tingkat kemiskinan di 33 provinsi di Indonesia periode 2014-2018. Variabel rasio kredit/PDRB berpengaruh negatif dan signifikan terhadap tingkat kemiskinan di 33 provinsi di Indonesia periode 2014-2018. Variabel pertumbuhan ekonomi berpengaruh negatif dan tidak signifikan terhadap tingkat kemiskinan di 33 provinsi di Indonesia periode 2014-2018. Variabel inflasi berpengaruh negatif dan tidak signifikan terhadap tingkat kemiskinan di 33 provinsi di Indonesia periode 2014-2018. Variabel tingkat pengangguran berpengaruh positif dan signifikan terhadap tingkat kemiskinan di 33 provinsi di Indonesia selama periode penelitian.

\section{Saran}

Karena keterbatasan data, penelitian ini menggunakan data sekunder yang tersedia di Bank Indonesia dan Badan Pusat Statistik, maka pengukuran dimensi kualitas tidak dilakukan. Pengukuran terhadap dimensi ini masih sulit untuk dilakukan dan saat ini beberapa lembaga internasional yang peduli terhadappengembangan inklusi keuangan sedang menyusun indikator dari dimensi kualitas beserta alat analisis yang digunakan. Secara umum, The Alliance for Financial Inclusion (AFI) telah menyepakati prinsipprinsip yang digunakan dalam menyusun indikator dari dimensi kualitas, meliputi ringkas, spesifik, sederhana, adanya perbaikan, dan perspektif nasabah. Pengukuran dimensi kualitas dapat didekati salah satunya melalui pengukuran tingkat literasi keuangan. Tingkat literasi keuangan mengacu pada skor yang dibangun oleh OECD (Organization Cooperation and Development). Skor literasi keuangan ini dibangun dari tiga dimensi, yaitu pengetahuan keuangan, sikap terhadap keuangan, dan perilaku keuangan yang diagregasi menjadi skor total untuk menggambarkan tingkat literasi keuangan suatu negara.

\section{Ucapan terima kasih}

Peneliti mengucapkan terima kasih pada pihak-pihak yang telah membantu dalam proses penelitian dan penulisan artikel ini. Bank Indonesia dan Badan Pusat Statistik sebagai penyedia dana, rekan-rekan peneliti dan mahasiswa yang telah memberikan sumbang saran dan pemikiran yang memperkaya artikel ini.

\section{DAFTAR PUSTAKA}

Abimbola, A., Olokoyo, F. O., Babalola, O., \& Farouk, E. (2018). Financial inclusion as a catalyst for poverty reduction in Nigeria. International Journal of Scientific Research and Management, 6(06),481-490,https://doi.org/10.18535/ijsrm/v6i6. em06

Bakari, Ibrahima Hassan. dkk. (2019). An examination of the impact of financial inclusion on poverty reduction: an empirical evidence from Sub-Saharan Africa. International Journal of Scientific and Research Publications, 9(1), 239-252 doi: 10.29322/ IJSRP.9.01.2019.p8532.

Baltagi, Badi H. (2005). Econometric Analysis of Panel Data. $3^{\text {rd }}$ Ed. West Sussex: John Wiley and Sons Ltd: England

Bank Indonesia. (2014). Booklet Keuangan Inklusif. Bank Indonesia: Jakarta

Coulibali, Aïsatta dan Yogo, Urbain Thierry. (2016). Access to Financial Services and Working Poverty in Developing Countries. Études et Documents, $\mathrm{n}^{\circ} 20$, CERDI. Id: halshs-01403001 https://halshs.archives-ouvertes.fr/halshs-01403001 
Demirgüç-Kunt, Asli; Levine, Ross. (2008). Finance, Financial Sector Policies, and Long-Run Growth. Policy Research Working Paper; No. 4469. World Bank, Washington, DC. World Bank. https://openknowledge.worldbank.org/handle/ 10986/ 6443 License: C.C BY 3.0 IGO.

Gujarati, D.N. (2012). Dasar-Dasar Ekonometrika. 2nd Ed. Salemba Empat: Jakarta

Hannig, A., and S. Jansen. (2010). Financial Inclusion and Financial Stability: Current Policy Issues. ADBI Working Paper 259. Asian Development Bank Institute: Tokyo

Harnoto, Laurentius Bambang. (2008). Analisis Hubungan Antara Pertumbuhan Ekonomi dan Tingkat Kemiskinan. Lembaga Penelitian \& Pengabdian kepada Masyarakat. Universitas Sanata Dharma, Yogyakarta, Indonesia.

Hoover, Gary A. dan Geoffrey L. Wallace. (2003). Examining the Relationship between the Poverty Rate and Economics Conditions: A comparison of $1980 \mathrm{~s}$ 1990s. The University of Alabama. Economic, Finance and Legal Working Paper Series.No. 2006-031 http://www.lafollette.wisc.edu/publications/ workingpapers

Kadji, Yulianto. (2013). Kemiskinan Dan Konsep Teoritisnya. Guru Besar Kebijakan Publik Fakultas Ekonomi dan Bisnis UNG: Gorontalo

Mishkin, Frederic S. (2008). Ekonomi Uang, Perbankan, dan Pasar Keuangan. Edisi 8. Salemba Empat : Jakarta

Nasution, H., Nasution, Y., \& Yafiz, M. (2017). Analisis Financial Inclusion Terhadap Pemberdayaan Masyarakat Miskin Di Medan (Studi Kasus Pembiayaan Mikro Ss Ii Di Bank Sumut Syariah). Jurnal Ekonomi dan Bisnis Islam, 2(1). https://doi.org/ 10.32505/v4i1.1235

Ningsih, Desrini \& Andiny, Puti. (2018). Analisis pengaruh inflasi dan pertumbuhan ekonomi terhadap kemiskinan di Indonesia. Jurnal Samudra Ekonomika. 2(1), 5361

Retnowati, Diah dan Harsuti. (2017). Pengaruh pengangguran terhadap tingkat kemiskinan di Jawa Tengah. Journal \& Proceding FEB UNSOED, 6(1), 608-618

Reyes, G. P. (2010). Financial Inclusion Indicators for Developing Countries: The Peruvian Case. Superintendency of Banking: Peru

Sarma, M. (2012). Index of financial inclusion-a measure of financial sector inclusiveness. Berlin Working Papers on Money, Finance, Trade and Development, 7, 1-37

Siyan, Peter. dkk. (2016). Unemployment and Inflation: Implication on Poverty Level in Nigeria. Munich Personal RePEc Archive. No. 79765, Diakses dalam https://mpra.ub.uni-muenchen.de/79765/

Ummah, Bintan Badriatul. dkk. (2015). Analisis Inklusi Keuangan dan Pemerataan Pendapatan di Indonesia. Jurnal Ekonomi dan Kebijakan Pembangunan. Vol.4, No.1, 1-27

Widarjono, Agus. (2013). Ekonometrika Pengantar dan Aplikasinya Disertai Panduan Eviews.UPP STIM YKPN: Yogyakarta

Williams, Harley Tega. dkk. (2017). Role of Financial Inclusion in Economic Growth and Poverty Reduction in a Developing Economy. Internal Journal of Research in Economics and Social Sciences (IJRESS), 7(5), 265-271

Zuhdiyaty, Noor dan Kaluge, David. (2017). Analisis Faktor-Faktor yang Mempengaruhi Kemiskinan di Indonesia Selama Lima Tahun Terakhir (Studi Kasus Pada 33 Provinsi). JIBEKA, 11(2), 27 - 31 